\title{
Utilization of $\mathrm{Nano}-\mathrm{TiO}_{2}$ as an Influential Additive for Complementing Separation Performance of a Hybrid PVDF-PVP Hollow Fiber: Boron Removal from Leachate
}

\author{
Hasfalina Che Man ${ }^{1,2, *} \mathbb{D}$, Mohammed Umar Abba ${ }^{1,3} \mathbb{D}^{\mathbb{D}}$, Mohammed Abdulsalam ${ }^{1,4}$, \\ Raba'ah Syahidah Azis ${ }^{5,6} \oplus^{\circ}$, Aida Isma Idris ${ }^{7}$ and Muhammad Hazwan Hamzah ${ }^{1,2} \mathbb{C}$ \\ 1 Department of Biological and Agricultural Engineering, Faculty of Engineering, Universiti Putra Malaysia, \\ Serdang 43400, Malaysia; gs51611@student.upm.edu.my (M.U.A.); gs50431@student.upm.edu.my (M.A.); \\ hazwanhamzah@upm.edu.my (M.H.H.) \\ 2 Smart Farming Technology Research Centre, Level 6, Blok Menara, Faculty of Engineering, \\ Universiti Putra Malaysia, Serdang 43400, Malaysia \\ 3 Department of Agricultural and Bioenvironmental Engineering, Federal Polytechnic Mubi, \\ Mubi 650221, Nigeria \\ 4 Department of Agricultural and Bio-Resources, Ahmadu Bello University, Zaria 810107, Nigeria \\ 5 Department of Physics, Faculty of Science, Universiti Putra Malaysia, Serdang 43400, Malaysia; \\ rabaah@upm.edu.my \\ 6 Materials Synthesis and Characterization Laboratory (MSCL), Institute of Advanced Technology (ITMA), \\ Universiti Putra Malaysia, Serdang 43400, Selangor, Malaysia \\ 7 Department of Chemical Engineering, Faculty of Engineering, Segi Universiti Malaysia, Petaling Jaya, \\ Selangor 47810, Malaysia; aidaisma@segi.edu.my \\ * Correspondence: hasfalina@upm.edu.my; Tel.: +60-397-694-340
}

Received: 25 September 2020; Accepted: 10 October 2020; Published: 28 October 2020

\begin{abstract}
The continuous increase in anthropogenic activities resulting in an increase in boron concentration in the environment is becoming a serious threat to public health and the ecosystem. In this regard, a hybrid polyvinylidene fluoride (PVDF)-polyvinyl pyrrolidone (PVP) hollow fiber was synthesized with hydrophilic nano-titanium oxide $\left(\mathrm{TiO}_{2}\right)$ at varied loadings of $0,0.5,1.0,1.5$, and $2.0 \mathrm{wt} \%$ using the phase inversion technique. The resultant membranes were characterized in terms of Scanning Electron Microscopy (SEM), Energy Dispersive X-ray Spectroscopy (EDX), contact angle, porosity, and zeta potential. The permeability flux was assessed using both pure water and leachate; also, rejection performance was evaluated based on boron removal from the leachate. The results revealed that the membrane with $1.0 \mathrm{wt} \%$ loading had the highest flux alongside an upturn in boron rejection percentage of $223 \mathrm{~L} / \mathrm{m}^{2} \cdot \mathrm{h}$ and $94.39 \%$, respectively. In addition, the lowest contact angle of $50.01^{\circ}$ was recorded with $1.0 \mathrm{wt} \% \mathrm{TiO}_{2}$ loading, and this implies that it is the most hydrophilic. Throughout the experiment cycles, the fiber with $1.0 \mathrm{wt} \% \mathrm{TiO}_{2}$ loading demonstrated a high flux recovery varying between $92.82 \%$ and $76.26 \%$ after $9 \mathrm{~h}$ filtration time. The physicochemical analysis of the permeate revealed that the boron concentration was significantly reduced to $0.43 \mathrm{mg} / \mathrm{L}$, which is far lower than the discharge limit of $1.0 \mathrm{mg} / \mathrm{L}$.
\end{abstract}

Keywords: nano- $\mathrm{TiO}_{2}$; hydrophilicity; flux; antifouling; hollow fiber; boron removal

\section{Introduction}

Accumulated landfill waste generates high-strength leachate, which eventually flows or percolates into the water bodies [1]. The percolated high-strength leachate contains several organic 
contaminants, including chemical oxygen demand, biological oxygen demand, ammonia, heavy metals, and boron [2-4]. Boron is a trivalent metalloid that often exists in the environment either as boric acid or borate ion [5]. It is usually released via anthropogenic activities, as well as through natural weathering processes. The United States Geological Survey (USGS) reported that about 4750 metric tons of boron were generated globally in 2006, which then increased to 9400 metric tons in 2016 due to industrialization and exponential population growth [6]. Some of the adverse effects of boron can lead to problems with the cardiovascular, coronary, nervous, and reproductive systems $[7,8]$. Boron exhibits a noticeable effect on plants, such as meristematic growth in tissues, disruption of roots and leaves, thickening of leaves, cracking of bark growth, and interference with cell formations, alongside delays in enzyme reactions [9]. Displays of yellowish spots on leaves and fruits along with rapid deterioration and untimely expiration of plants are all due to excess boron [10]. Owing to the potential adverse effects on human health, the Department of the Environment (DOE) of Malaysia and the World Health Organization (WHO) both set regulatory discharge limits to a maximum of 1.0 and $0.5 \mathrm{mg} / \mathrm{L}$ in drinking water, respectively [11]. This implies that the need for adequate treatments of industrial effluent to relegate boron concentration to an acceptable discharge limit is unavoidable.

Several methods have been attempted by researchers to eliminate the boron from a generated effluent before discharge. The various methods employed include chemical precipitation [12], activated carbon [13,14], electrocoagulation [15,16], chemical coagulation [17], and reverse osmosis [18] and adsorption [19]. Collectively, some of the most noticeable drawbacks include low adsorption capacity, sludge generation, high cost of chemicals, and frequent fouling during their application. Consequently, this could significantly increase the running cost and operation downtime; as such, it may be unsustainable for large-scale applications. Thus, this necessitated the need for a more robust, cost-effective, and efficient method for boron removal. The membrane-based purification process gained significant attention in the last two decades because of its promising performance in separating boron from wastewater as well as drinking water $[20,21]$. However, its application is limited by fouling, which usually results in a reduction in flux, excessive energy input, and unsustainable running cost.

Several studies have shown that the fouling effect observed with most of the polymeric membranes is not only due to the foulants' properties and the operating condition, but intrinsic hydrophobic properties could also be a major factor. Therefore, in order to minimize the fouling challenges, the use of hydrophilic nanoparticle additives to modify the membrane is widely practiced by researchers [22-25]. Basically, nanoparticles are characterized with a micropore structure and distinctive large surface-to-volume ratio, as well as surface functional groups such as $\mathrm{OH}$ [26]. These qualities make it compatible with establishment of a stable matrix structure or a link with most of the polymers commonly used for membrane fabrication [27]. Various nanoparticles such as $\mathrm{ZnO}$ [21,22], $\mathrm{TiO}_{2}$ [28], $\mathrm{Ag}_{2} \mathrm{O}_{3}$ [24,25], $\mathrm{Al}_{2} \mathrm{O}_{3}$ [29], graphene oxide [30,31], $\mathrm{MgO}$ [32], and $\mathrm{CuO}$ [33] are commonly applied for modifying polymeric membranes to improve its hydrophilicity properties.

Among hydrophilic additives, $\mathrm{TiO}_{2}$ has received an upturn in wider applications, and this might be due to its excellent compatibility, stable linkage with the polymer/co-polymer, and its ability to generate a hydroxyl functional group via the deprotonation process $[34,35]$. This could support the mitigation of the fouling tendencies of the polymeric membrane [36]. The incorporation of $\mathrm{TiO}_{2}$ nanoparticles (NPs) into the polyvinylidene fluoride (PVDF) membrane polymeric matrix makes the surface slightly more negative [37]. Due to their sensing properties, $\mathrm{TiO}_{2}$-based structures are also used for the creation of gas-sensing devices [38,39]. Moreover, the blending of $\mathrm{TiO}_{2} \mathrm{NPs}$ into the membrane matrix was expected to provide an additional advantage in declining fouling propensity [27], thereby making the membrane matrix hydrophilic. For instance, Damodar et al. [36] blended $\mathrm{TiO}_{2}$ nanoparticles in a PVDF dope solution, and the results showed that $\mathrm{TiO}_{2}$ addition significantly improves the pore size and hydrophilicity of the modified membrane. Oh et al. [40] also noticed a significant improvement in fouling resistance of the PVDF-Ultrafiltration membrane when $\mathrm{TiO}_{2}$ nanoparticles were blended into the matrix structure. Likewise, Guangyong et al. [41] and $\mathrm{Zhang}$ et al. [42] blended $\mathrm{TiO}_{2}$ nanoparticles to improve the antifouling properties of the PVDF matrix. 
Despite the potential of the membrane filtration technique for the separation process and the potential of $\mathrm{TiO}_{2}$ to improve its hydrophilic properties, information on the application of modified hybrid nano PVDF-polyvinyl pyrrolidone (PVP) for boron separation from leachate remains very scarce. In this regard, this study aims to develop a hybrid PVDF membrane accreted with different levels of $\mathrm{TiO}_{2}$ nanoparticles $(0,0.5,1.0,1.5$, and $2.0 \mathrm{wt} \%)$ using the phase inversion (PI) technique. The resultant modified hollow fibers were characterized using Scanning Electron Microscopy (SEM), Energy Dispersive X-ray Spectroscopy (EDX), and goniometric analysis to measure the contact angle. The permeability flux and the performance for boron removal from leachate were evaluated.

\section{Experimental Methods}

\subsection{Materials}

The main membrane-forming material used in this study includes granular PVDF polymer procured from Arkema (Kynar ${ }^{\circledR} 760$ Inc. Philadelphia, PA, USA); N, N-dimethylacetamide (dimethylacetamide (DMAc); Wako Pure Chemical Industries Ltd., Osaka, Japan) was used without further purification to liquefy the polymer. PVP additive was used as co-polymer to facilitate pore formation, and it was ordered from Sigma-Aldrich (Milwaukee, WI 53,209 USA) (MW = 10,000 Da). $\mathrm{TiO}_{2}$ (Degussa P25, average particle size $\sim 21 \mathrm{~nm}$; heat shock $\mathrm{pH} 7, \geq 98 \%$ analytical grade) was supplied by Sigma-Aldrich (Milwaukee, WI 53,209 United States) and utilized without prior purification. The landfill leachate was collected into an airtight container from a wastewater treatment plant located in Selangor, Malaysia. The collected leachate samples were preserved at $4{ }^{\circ} \mathrm{C}$ in a chiller to avert any possible biochemical reactions.

\subsubsection{Dope Formulation}

Table 1 shows the compositional solutions of $\mathrm{PVDF} / \mathrm{DMA}_{\mathrm{C}} / \mathrm{PVP} / \mathrm{TiO}_{2}$, prepared under a steady stirring at $250 \mathrm{rpm}$ and $60^{\circ} \mathrm{C}$ for a period of $24 \mathrm{~h}$ to ensure a homogenous mixture and to eliminate air bubbles. In addition, PVDF granules were added to the prepared solutions and subjected to a higher stirring velocity of $400 \mathrm{rpm}$ at $100{ }^{\circ} \mathrm{C}$ (Monotaro; C-MAG HS7, Amagasaki, Hyogo, 660-0876, Japan) for another $24 \mathrm{~h}$. The higher stirring speed and elevated temperature facilitate the dissolving of the granules to give a homogenous dope. Afterward, the final dope solutions were sonicated for $30 \mathrm{~min}$ in a water bath at a temperature of $45^{\circ} \mathrm{C}$. The sonicated dope solutions were allowed to cool at room temperature and spun into hollow fibers using the phase inversion technique.

Table 1. Dope chemical composition.

\begin{tabular}{|c|c|c|c|c|}
\hline Composition & $\begin{array}{c}\text { Polymer (PVDF) } \\
(w t \%)\end{array}$ & $\begin{array}{c}\text { Solvent }\left(\mathrm{DMA} \mathrm{A}_{\mathrm{C}}\right) \\
(w \mathrm{t} \%)\end{array}$ & $\begin{array}{c}\text { Additive PVP } \\
(w t \%)\end{array}$ & $\mathrm{TiO}_{2}(w \mathrm{t} \%)$ \\
\hline Neat & 18.0 & 77.0 & 5.0 & 0.0 \\
\hline Modified (0.5) & 18.0 & 76.5 & 5.0 & 0.5 \\
\hline Modified (1.0) & 18.0 & 76.0 & 5.0 & 1.0 \\
\hline Modified (1.5) & 18.0 & 75.5 & 5.0 & 1.5 \\
\hline Modified (2.0) & 18.0 & 75.0 & 5.0 & 2.0 \\
\hline
\end{tabular}

\subsubsection{Spinning of Nano-Hybrid PVDF/PVP/DMA $/ \mathrm{TiO}_{2}$ - Hollow Fiber Membrane}

The dry-jet wet spinning method was employed to spin the dope fed into the annular spinneret [42]. The extrusion needle of the annular spinneret had an inner and outer diameter of 0.55 and $1.15 \mathrm{~mm}$, respectively. Distilled and tap water were used as the internal and external coagulant, respectively. The pick speed control, collecting drum speed, extrusion rate, air distance, external coagulant temperature, room temperature, and room humidity parameters were all maintained constant at $7 \mathrm{rpm}, 9 \mathrm{rpm}, 5 \mathrm{~mL} / \mathrm{min}, 10 \mathrm{~cm}, 25^{\circ} \mathrm{C}, 29.5 \pm 1{ }^{\circ} \mathrm{C}$, and $72.7 \%$, respectively. Then, the spun fibers were soaked in a continuous flow water bath for $24 \mathrm{~h}$ to dislodge all the residual solvents. Afterward, 
post-treatments were administered to the fibers to mitigate shrinkage by dipping fibers in an ethanol solution for $12 \mathrm{~h}$; they were then transferred into a $10 \mathrm{w} \%$ glycerol aqueous for another $5 \mathrm{~h}$. To ensure complete dehydration, the treated membranes were air-dried for $24 \mathrm{~h}$ at $70{ }^{\circ} \mathrm{C}$. Table 2 presents the spinning parameters of the dry-jet spinning.

Table 2. Spinning parameters.

\begin{tabular}{cc}
\hline Parameters & Condition \\
\hline Spinnerets size & $1.15 \mathrm{~mm}$ OD $/ 0.55 \mathrm{~mm} \mathrm{ID}$ \\
Dope extrusion rate & $5 \mathrm{~mL} / \mathrm{min}, 16.67 \mathrm{rpm}$ \\
Bore fluid composition & water \\
Air gap & $5 \mathrm{~cm}$ \\
Internal/external coagulant & Water \\
Coagulant bath temperature & Room temperature $\left(25^{\circ} \mathrm{C}\right)$ \\
Collection drum speed & 9 rpm \\
Washing bath & Water \\
\hline
\end{tabular}

\subsection{Membrane Characterization}

\subsubsection{Morphological Study}

The digital microstructure of the surface and the cross-section of the spun membranes were captured using Scanning Electron Microscopy (SEM) (Model: TM 3000, Hitachi, Tokyo, Japan) at a voltage of $20 \mathrm{kV}$. Initially, samples for the cross-sectional imaging were frozen in liquid nitrogen. This is to aid sharp fracturing and to ensure a clearer structure. The fractured samples were coated with a thin gold layer and then mounted on the sample's holder with a carbon tap. Thereafter, the microstructures were examined using an SEM (S-3400, Hitachi, Tokyo, Japan) at an accelerated voltage of $20 \mathrm{kV}$.

\subsubsection{Energy Dispersive X-ray Spectroscopy (EDX) Analysis}

EDX analysis of the membrane's samples with varied loading of $\mathrm{TiO}_{2}$ was conducted using a Thermo Scientific instrument; $1 \mathrm{~g}$ of the membrane samples at a different dosage of $\mathrm{TiO}_{2}$ was used for the EDX analysis using an SEM (TM 3000, Hitachi, Tokyo, Japan) to examine the distribution, dimensions, and elemental composition of nano-hybrid membranes.

\subsubsection{Hydrophilic Analysis}

The hydrophilicity of the spun fibers was determined based on the water drop surface contact angle using a goniometer (OCA 15EC, Data Physics, Succasunna, NJ 07,876 USA). Initially, a dried membrane sample was attached tightly on the glass panel by using double-sided carbon tape. About $1 \mu \mathrm{L}$ of deionized water (contact liquid) was dropped on the surface of the membrane by using a microneedle of the goniometer. The instrument automatically captured the angle of the water droplets. For each of the samples, the contact angle was measured in a replicate of 10 , and the average value was considered. This procedure is to minimize the level of bias in the data.

\subsubsection{Porosity Analysis}

The gravimetric method was employed in determining the porosity of the membrane [28]. About $40 \mathrm{~cm}$ length of the membrane's samples, comprising of ten (10) pieces each, were prepared. The opened ends of the samples were sealed using epoxy resin and then soaked in distilled water for $5 \mathrm{~h}$ at room temperature $\left(26 \pm 1{ }^{\circ} \mathrm{C}\right)$. The soaked fibers were gently removed, and then the traces of water drops on the surface were mopped using dry tissue paper. The soaked-mopped fibers were weighed as wet membrane $\left(\mathrm{M}_{\mathrm{W}}\right)$. The soaked membranes were then oven-dried for $24 \mathrm{~h}$ at $70{ }^{\circ} \mathrm{C}$, and weight was 
measured as dry membrane $\left(\mathrm{M}_{\mathrm{d}}\right)$. Subsequently, the porosity $(\varepsilon)$ of each membrane was determined using Equation (1) [43-45].

$$
\varepsilon(\%)=\frac{1}{\rho_{\mathrm{w}}}\left(\frac{\mathrm{M}_{\mathrm{w}}-\mathrm{M}_{\mathrm{d}}}{\mathrm{V}}\right) \times 100
$$

where $\varepsilon$ is the membrane porosity (\%), $\rho_{\mathrm{W}}$ is the density of water, $\mathrm{M}_{\mathrm{W}}$ is the weight of wet membrane, $M_{d}$ is the weight of dry membrane, and $V$ is the volume of the membrane sample.

\subsection{Evaluation of Membrane Performances}

\subsubsection{Permeability and Flux Performance}

The dead-end permeation device fitted with a membrane module cell was used to assess filtration or permeability efficiency. A suction pressure was provided to the membrane by a peristaltic pump (PLP 6000 manufactured by Dülabo Laborgeräte, Wertheim, Germany). Each of the modules consisted of 25 membrane units with an equal length of $40 \mathrm{~cm}$. The membrane was initially compacted for $30 \mathrm{~min}$ at a pressure of $0.4 \mathrm{MPa}$ to ensure a steady permeability, while the successive filtration of leachate was conducted at a lower pressure of $0.3 \mathrm{MPa}$. The volume of the permeate collected was measured at an interval of $50 \mathrm{~min}$ for a total filtration period of $200 \mathrm{~min}$. The flux of the spun membranes filtrating the pure water $\left(\mathrm{J}_{\mathrm{W}}\right)$ and leachate $\left(\mathrm{J}_{\mathrm{L}}\right)$ was calculated using Equation (2).

$$
\mathrm{J}=\frac{\mathrm{V}}{\mathrm{A} \cdot \mathrm{t}}
$$

where $\mathrm{J}$ is the flux in $\left(\mathrm{L} / \mathrm{m}^{2} \cdot \mathrm{h}\right), \mathrm{J}_{\mathrm{L}}, \mathrm{V}$ is the volume of the permeate $(\mathrm{L}), \mathrm{A}$ is the effective membrane area $\left(\mathrm{m}^{2}\right)$, and $\mathrm{t}$ is the time in $(\mathrm{h})$.

\subsubsection{Rejection Performance (Re\%)}

The rejection performance of the spun fibers was evaluated based on boron removal from leachate. The initial concentration of boron $\left(C_{p}\right)$ in the leachate was $8.2 \mathrm{mg} / \mathrm{L}$, which was determined using an ultraviolet spectrophotometric technique (DR4000U, HACH, Loveland, CO, USA) at an absorbance wavelength of $605 \mathrm{~nm}$. The concentration of the boron in permeate after filtration was also measured as $\left(\mathrm{C}_{\mathrm{f}}\right)$. Thus, boron rejection efficiencies were measured using Equation (3).

$$
\mathrm{R}=\left(1-\frac{\mathrm{C}_{\mathrm{p}}}{\mathrm{C}_{\mathrm{f}}}\right) \times 100
$$

where $\mathrm{R}$ is the boron rejection (\%), and $\mathrm{C}_{\mathrm{p}}$ and $\mathrm{C}_{\mathrm{f}}$ are the boron concentrations in the permeate $(\mathrm{mg} / \mathrm{L})$ and feed $(\mathrm{mg} / \mathrm{L})$, respectively.

\subsubsection{Antifouling and Reusability Analysis}

The resultant membranes were subjected to three cycles of filtration with a total operating time of $9 \mathrm{~h}$. Every filtration cycle lasted for $200 \mathrm{~min}$, and was then reapplied for another cycle of filtration after a simple backwash using running tap water for 30 min only. Throughout the experiments, the flux $\left(\mathrm{J}_{\mathrm{L}}\right)$ was determined at an interval of $50 \mathrm{~min}$ using the corresponding volume of the permeate collected. The antifouling performance of the membranes was evaluated based on the relative flux recovery (\%RFR) and flux recovery ratio (\%FRR), as expressed in Equations (4) and (5), respectively [41,42,46,47].

$$
\begin{gathered}
\text { Relative flux reduction \%RFR }=\left[1-\frac{\mathrm{J}_{\mathrm{L}}}{\mathrm{J}_{\mathrm{W}}}\right] \times 100 \\
\text { Flux recovery ratio \%FRR }=\left(\frac{\mathrm{J}_{\mathrm{w} 2}}{\mathrm{~J}_{\mathrm{w}}}\right) \times 100
\end{gathered}
$$


where $\mathrm{J}_{\mathrm{L}}$ is the leachate flux, $\mathrm{J}_{\mathrm{W}}$ is the pure water flux, and $\mathrm{J}_{\mathrm{w} 2}$ is the remeasured pure water flux after washing, all in $\left(\mathrm{L} / \mathrm{m}^{2} \cdot \mathrm{h}\right)$.

\subsection{Zeta Potential Measurement}

Using an adjustable gap cell, the zeta potentials of PVDF-PVP and modified PVDF-PVP-TiO 2 membranes were measured using an electrokinetic analyzer from Anton Paar SurPASS (Berlin Germany). The measurements were carried out using an electrolyte solution purged with nitrogen at $0.1 \mathrm{M} \mathrm{KCl}$. During measurements, $0.1 \mathrm{M} \mathrm{NaOH}$ and $0.05 \mathrm{M} \mathrm{HCl}$ were used to adjust the $\mathrm{pH}$ level.

\subsection{Analytical Method}

The Carmine process was employed to measure the boron concentration present in the leachate before and after treatment. Basically, the boron ver 3 reagents were introduced into a $75 \mathrm{~mL}$ concentrated $\mathrm{H}_{2} \mathrm{SO}_{4}$ solution to determine boron concentration. A $2 \mathrm{~mL}$ leachate sample and deionized water were correctly pipetted into a $125 \mathrm{~mL}$ flask each after $5 \mathrm{~min}$ of reaction. A $35 \mathrm{~mL}$ boron version $3 / \mathrm{H}_{2} \mathrm{SO}_{4}$ solution was applied to each flask. The prepared sample was placed into the cell holder of the ultraviolet-vis spectrophotometer (DR/4000u HACH, Colorado, USA) at a wavelength of $620 \mathrm{~nm}$ to determine the concentration of the leachate sample. All deionized water utilized in the experiments was obtained from the Milli-Q water purification system (18 MQ cm).

\section{Results and Discussion}

\subsection{Influence of $\mathrm{TiO}_{2}$ on Membrane Characteristics}

\subsubsection{Structural Morphology}

Figure 1 shows the SEM microstructure of the cross-section of the various membranes prepared with a varied $\mathrm{TiO}_{2}$ dosage. Blending $\mathrm{TiO}_{2}$ nanoparticles into membrane dope results in more pores of greater size on the surface of the membrane [48]. Essentially, as $\mathrm{TiO}_{2}$ loading increases $(0,0.5,1.0$, 1.5 , and $2 \mathrm{wt} \%$ ), the finger-like pores of the modified membrane become larger and the number of micropores structures increases considerably [32]; this might be due to the nucleation process alongside crosslinks developed between the $\mathrm{TiO}_{2}$ and the polymeric materials [32]. However, homogeneous dispersion of $\mathrm{TiO}_{2}$ on the membrane matrix was noted from 0.5 to $1.0 \mathrm{wt} \%$. Conversely, at a greater $\mathrm{TiO}_{2}$ concentration (i.e., 1.5 and $2 \mathrm{wt} \%$ ), these nanoparticles appeared to agglomerate and formed larger nanoparticles, leading to pore blockage and reduction in water flow [49].

\subsubsection{EDX Elemental Analysis}

Figure 2 shows the SEM and elemental composition of membranes made from the different dosages of $\mathrm{TiO}_{2}-0,0.5,1.0,1.5$, and $2.0 \mathrm{wt} \%$, respectively-in the presence of the PVP additive. The neat membrane has only oxygen and carbon in the elemental composition. Membrane accreted with $0.5 \mathrm{wt} \% \mathrm{TiO}_{2}$ dosage displayed elemental composition of $45 \% \mathrm{C}, 39.8 \% \mathrm{O}$, and $15.3 \% \mathrm{Ti}$. It was observed that the Ti percentage in the elemental composition increased with an increase in $\mathrm{TiO}_{2}$ dosage in the dope. Ti composition increases from $15.3 \%$ to $35.5 \%$. However, at higher loading of $\mathrm{TiO}_{2}$ $(2.0 \mathrm{wt} \%)$, the $\mathrm{O}$ compositions were reduced to $44.6 \%$. As depicted in Figure 2, 0.5 and $1.0 \mathrm{wt} \% \mathrm{TiO}_{2}$ loading present a free agglomeration. In contrast, membranes with 1.5 and $2.0 \mathrm{wt} \% \mathrm{TiO}_{2}$ loading display heterogeneous dispersion and clustering of particles, which led to agglomeration and an increase in viscosity in the dope [50]. 

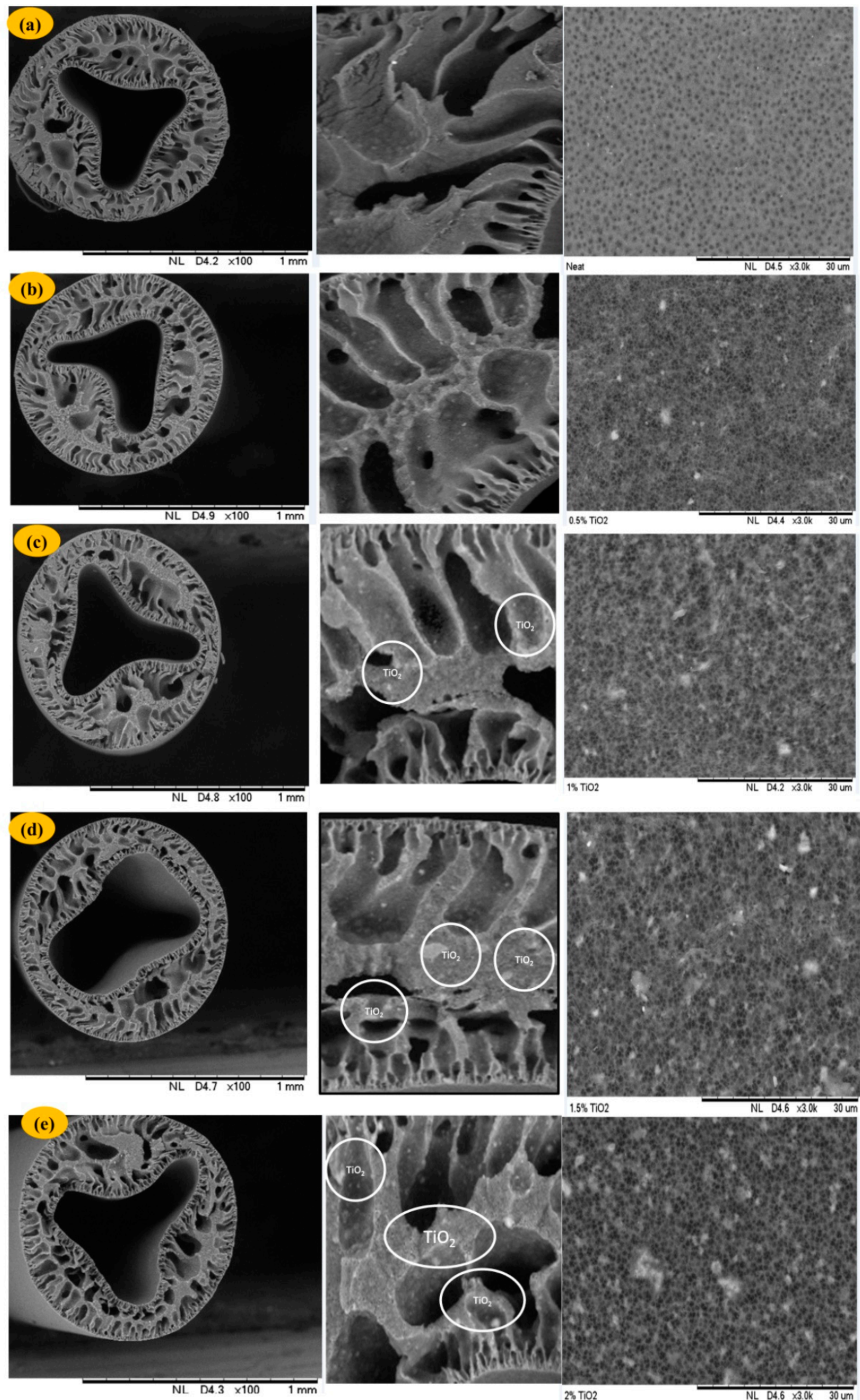

Figure 1. Scanning Electron Microscopy (SEM) pictures (cross and exterior surface) of polyvinylidene fluoride (PVDF) membranes made from separate levels of $\mathrm{TiO}_{2}$ : (a) 0, (b) 0.5, (c) 1.0, (d) 1.5, and (e) $2.0 \mathrm{wt} \%$ in the presence of polyvinyl pyrrolidone (PVP). 

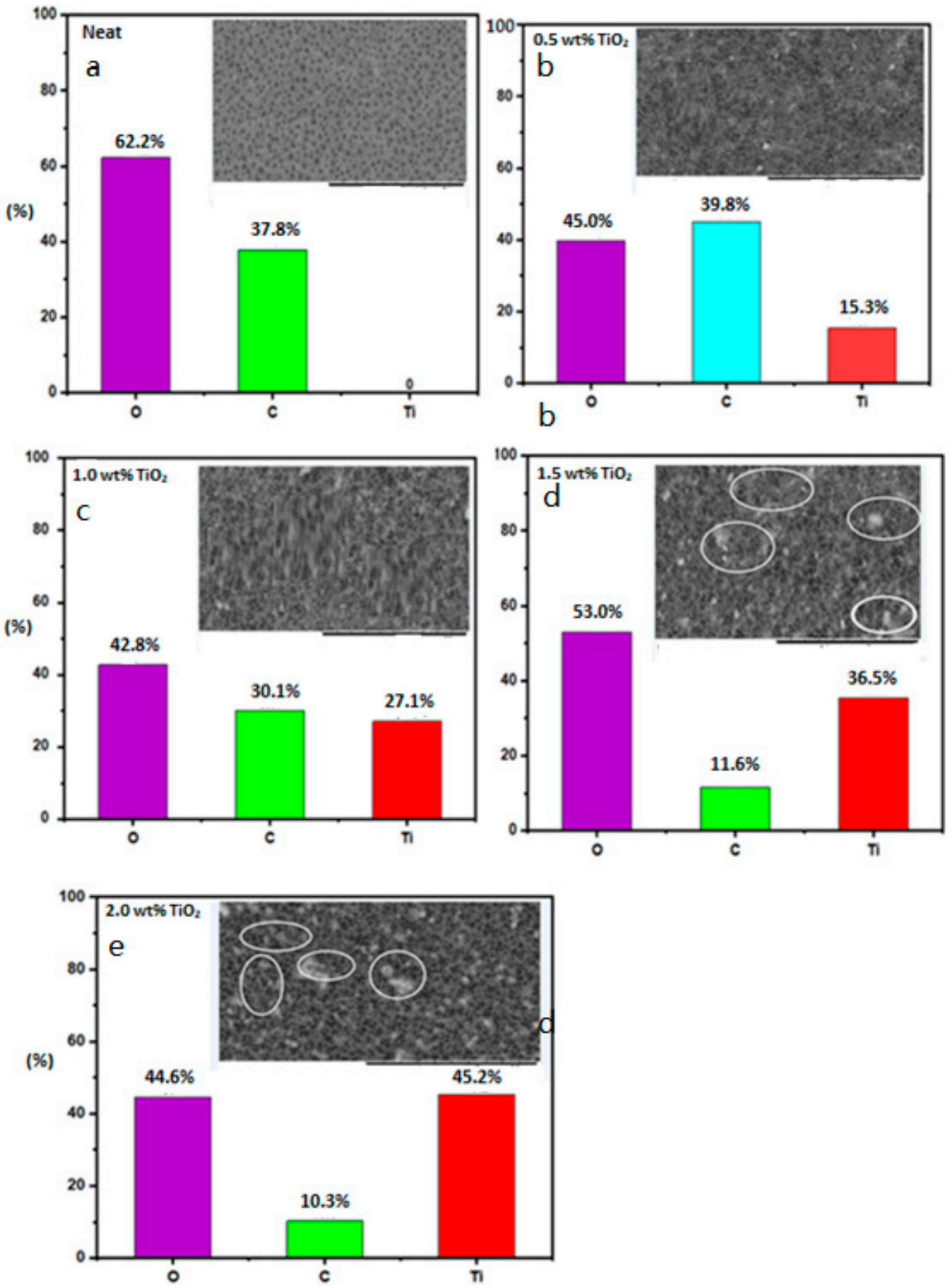

Figure 2. SEM/elemental composition of the PVDF/PVP membrane at different dosages of $\mathrm{TiO}_{2}$ : (a) neat, (b) 0.5 , (c) 1.0 , (d) 1.5 , and (e) $2.0 \mathrm{wt} \%$.

\subsubsection{Hydrophilicity Analysis}

The contact angle is often used to describe the surface hydrophilicity [51]. The contact angle of the neat and modified membrane is shown in Figure 3. The addition of $\mathrm{TiO}_{2}$ nanoparticles into the polymeric dope solution produced a clear distinction in both hydrophilicity and flux [52]. The modified membrane with $1.0 \mathrm{wt} \% \mathrm{TiO}_{2}$ concentration exhibited higher hydrophilicity with the lowest contact angle of $50.01^{\circ}$, while the neat membrane had a contact angle of $66.71^{\circ}$. Further increase in $\mathrm{TiO}_{2}$ loading (1.5 and $2.0 \mathrm{wt} \%)$ resulted in agglomeration of the nanoparticles within the membrane matrix, a decline in hydrophilicity, and a slight increase in the contact angle. This can be attributed to heterogenous distribution of the nanoparticles, a decrease in surface potential, and blockage of micropores on 
the membrane surface $[53,54]$. Based on these results and previous studies, the presence of $\mathrm{TiO}_{2}$ nanoparticles in the matrix structure of the modified PVDF membrane improves its hydrophilicity. Furthermore, researchers have also shown that most polymeric membranes with good hydrophilic properties have a higher propensity to resist fouling $[48,55]$.

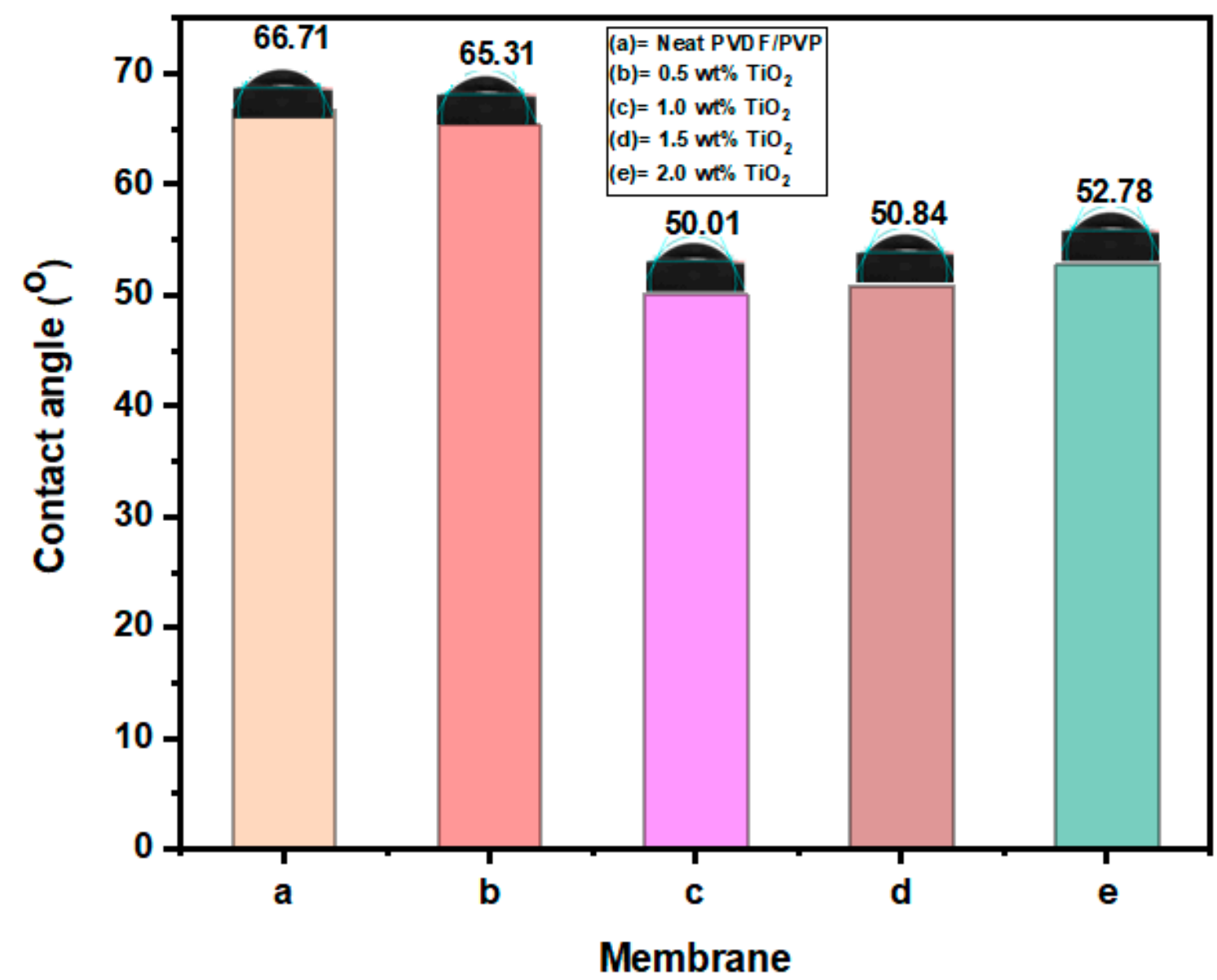

Figure 3. The contact angles of neat PVDF-PVP (a) and membranes modified with $\mathrm{TiO}_{2}(\mathbf{b}),(\mathbf{c})$, (d) and (e).

\subsubsection{Membrane Porosity}

Membrane porosity is greatly influenced by $\mathrm{TiO}_{2}$ loading into PVDF dope, as demonstrated in Figure 4 . The neat membrane (a) $0 \mathrm{wt} \%$ had the least porosity of $59.26 \%$, while the modified membranes had higher values of $68.54 \%, 85.50 \%, 80.90 \%$, and $64.90 \%$ for the dosages of (b) 0.5 , (c) 1.0 , (d) 1.5 , and (e) $2.0 \mathrm{wt} \%$ membranes, respectively. The large jump in porosity from $59.26 \%$ to $85.50 \%$ at $1.0 \mathrm{wt} \%$ loading is due to the incorporation of $\mathrm{TiO}_{2}$ nanoparticles in the PVDF matrix, which led to an increase in surface hydrophilicity compared to the neat PVDF membrane [56]. The membrane with $1.0 \mathrm{wt} \%$ $\mathrm{TiO}_{2}$ loading is more hydrophilic, with a contact angle of $50.01^{\circ}$. The improved hydrophilicity makes the membrane more hydrophilic, which results in a significant increase in porosity and flux [53,57]. However, a further increase in $\mathrm{TiO}_{2}$ loading (1.5-2.0 wt \%) results in a decline in porosity due to an increase in dope viscosity, which delayed the exchange rate between water and solvent, with resultant lower pore volume in the membrane structure [58,59]. However, the decrease in porosity observed with $2.0 \mathrm{wt} \% \mathrm{TiO}_{2}$ loading might be due to the effect of agglomeration and high viscosity on the dope [60]. Therefore, it can be presumed that excessive loading of $\mathrm{TiO}_{2}$ onto the membrane dope weakens the formation of the pores and could considerably diminish the porosity as well as the permeability of the resultant membrane. 


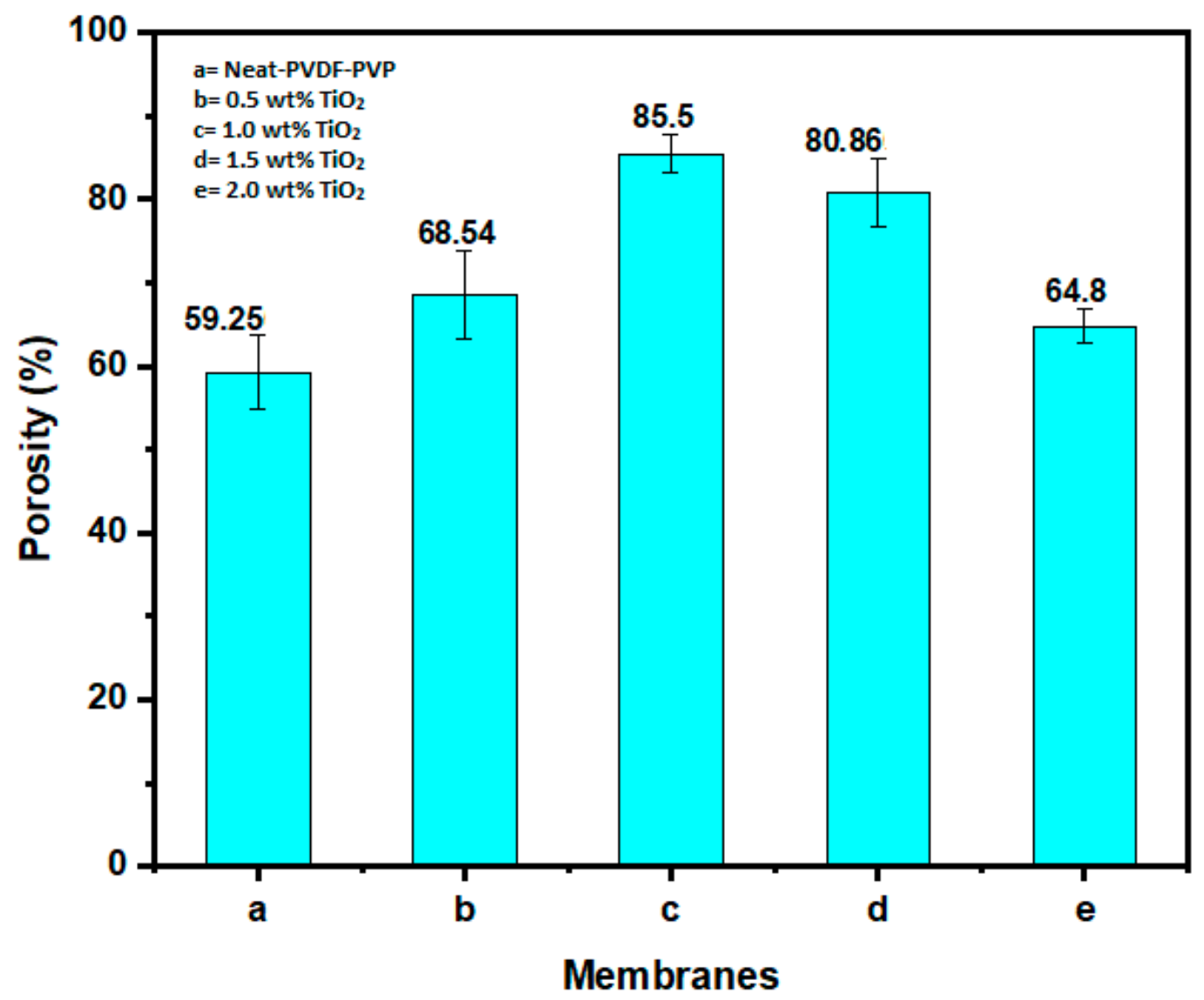

Figure 4. Porosity of neat PVDF-PVP (a) and nano-hybrid membranes modified with $\mathrm{TiO}_{2}(\mathbf{b}-\mathbf{e})$.

\subsection{Influence of $\mathrm{TiO}_{2}$ on Membrane Performance}

\subsubsection{Flux}

The permeate flux of the fabricated membrane at different $\mathrm{TiO}_{2}$ loadings is shown in Figure 5. The neat membrane recorded a flux of 125 and $109 \mathrm{~L} / \mathrm{m}^{2} \cdot \mathrm{h}$ for pure water and leachate filtration, respectively. In contrast, the modified membrane with the $1.0 \mathrm{wt} \% \mathrm{TiO}_{2}$ loading recorded more superior flux, with a magnitude of 223 and $172 \mathrm{~L} / \mathrm{m}^{2} \cdot \mathrm{h}$ for the pure water and leachate filtration, respectively. This shows that the modification of the membrane matrix using the $\mathrm{TiO}_{2}$ nanoparticles significantly improved its hydrophilicity [52]. However, it was noticed that at higher loading of $\mathrm{TiO}_{2}$ nanoparticles $(1.5 \mathrm{wt} \%)$, the flux for the pure water and leachate filtration declined to 207 and 156 $\mathrm{L} / \mathrm{m}^{2} \cdot \mathrm{h}$, respectively. This is due to the agglomeration effect of the nanoparticles on the membrane matrix [32]. This can be attributed to heterogenous distribution of the nanoparticles, a decrease in surface potential, and blockage of micropores on the membrane surface $[53,54]$. Furthermore, the presence of agglomeration particles within the matrix structure could skew the surface area interaction of the additive $\left(\mathrm{TiO}_{2}\right)$ and cause more roughness on the external part of the membrane [49]. Thus, this could relegate the hydrophilicity and then become more susceptible to fouling even at higher loading [32]. Membrane permeability could also be compromised due to blockage of pores, which hinders the passage of water [49]. Generally, the volume of flux in leachate filtration was noticeably smaller in comparison to pure water flux. This was perhaps due to the presence of more pollutants, particulates, and the colloidal matters in the leachate [22]. 


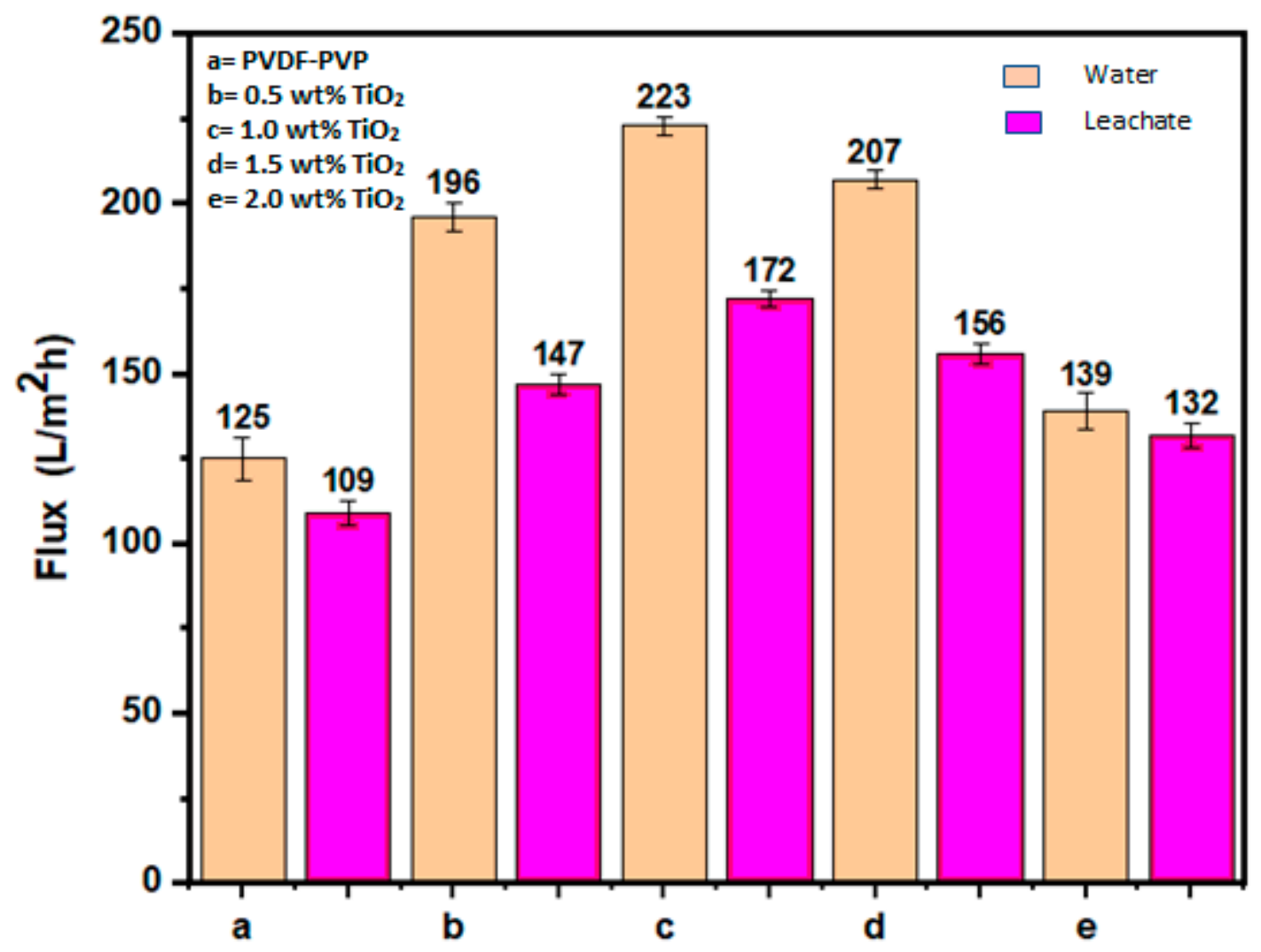

Figure 5. Flux of neat PVDF-PVP (a) and nano-hybrid membranes modified with $\mathrm{TiO}_{2}(\mathbf{b}-\mathbf{e})$.

\subsubsection{Boron Rejection}

Boron rejection by neat and modified membranes is shown in Figure 6. The modified membrane with $1.0 \mathrm{wt} \% \mathrm{TiO}_{2}$ loading demonstrated significant boron removal with $94.75 \%$ and $0.43 \mathrm{mg} / \mathrm{L}$ concentration, while the neat membrane recorded $72.43 \%$ boron removal and $2.4 \mathrm{mg} / \mathrm{L}$ concentration. The previous study on the high-performance $\mathrm{PVDF}-\mathrm{TiO}_{2}$ membrane for water treatment reported a similar finding [61]. Further loading of $\mathrm{TiO}_{2}$ nanoparticles in the dope from 1.5 to $2.0 \mathrm{wt} \% \mathrm{TiO}_{2}$ loading led to a decline in membrane rejection ( $89 \%$ and $88 \%$ ). This was as a result of changes in the morphology and structure of the membrane surface due to heterogeneous distribution of the nanoparticles [61]. The agglomeration of the particles localized the hydrophilic effect to particular points, while a major part of the matrix was free of the additive $\left(\mathrm{TiO}_{2}\right)$. Therefore, there will be skewed and inconsistent rejection performance of the modified membrane with higher loading. Based on this, it can be deduced that achieving a homogenous mixture of the additive at a certain loading is crucial to achieving good rejection performance.

The addition of $\mathrm{TiO}_{2}$ nanoparticles into the PVDF membrane matrix renders the surface more negative, and this might be due to the deprotonation process [36]. Essentially, the deprotonation takes place because the medium of the leachate feed solution is in an alkaline state, which makes the boron in the leachate become ionized into borate ion $\left(\mathrm{B}(\mathrm{OH})_{4}^{-}\right)$. In addition, the presence of the $\mathrm{TiO}_{2}$ in the matrix facilitates the formation of hydroxyl functional groups $(\mathrm{OH})$ on the surface of the membrane via deprotonation, and this made the membrane surface become more negatively charged [28,32]. The surging ionized borate species towards the membrane surface got rejected due to the like charge repulsion principles $[37,62]$. Consequently, this process assists in mitigating fouling susceptibility, thereby improving the rejection efficiency. 


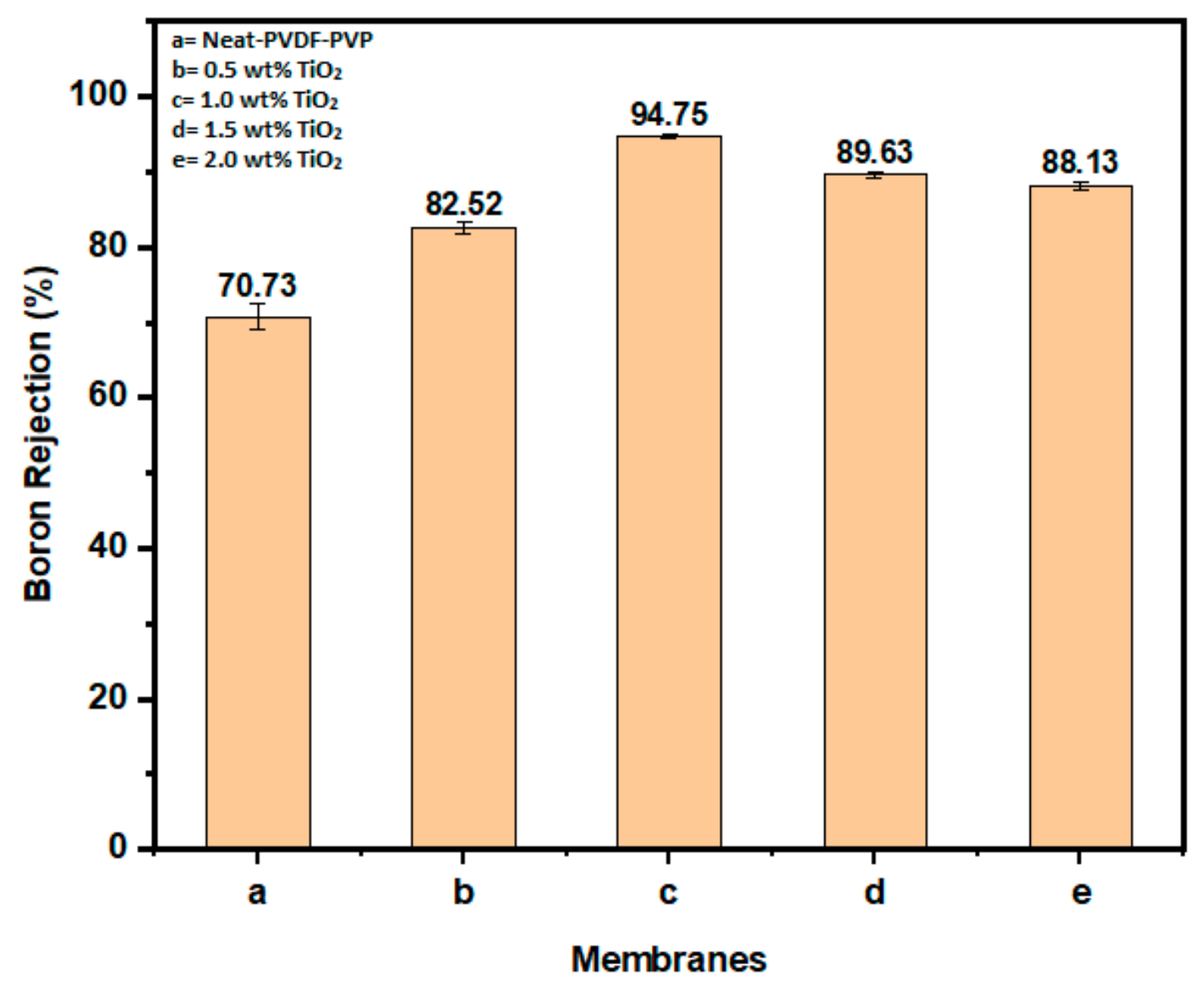

Figure 6. Boron rejection of neat PVDF-PVP (a) and membranes modified with $\mathrm{TiO}_{2}(\mathbf{b}-\mathbf{e})$.

Boric acid is hard to be removed via size exclusion due to its low molecular size ( $0.4 \mathrm{~nm})$, which is smaller than the membrane pore size [63]. The boron in the feed solution (leachate) exists as borate ion $\left(\mathrm{B}_{3}(\mathrm{OH})_{4}^{-}\right)$in alkaline conditions. In addition, the presence of dispersed $\mathrm{TiO}_{2}$ within the membrane matrix resulted in the formation of negative charges on the membrane surface [37]. Thus, the negatively charged borate ions were repelled upon approaching the membrane surface with like charges, resulting in high boron rejection [62]. The high jump in boron removal is attributed to high negative zeta potential recorded at $1.0 \mathrm{wt} \% \mathrm{TiO}_{2}$ loading rate, which results in a more considerable amount of hydroxide groups and changes in the overall structure of the membrane. The resultant borate ion repulsion inhibits the accumulation of hydrophobic substances on the membrane surface and pore wall. Based on this rejection phenomenon, separation efficiency and fouling control are enhanced. Figure 7 demonstrates the repulsion mechanism between borate ions $\left(\mathrm{B}_{3}(\mathrm{OH})_{4}{ }^{-}\right.$and the $\mathrm{TiO}_{2}$ nano-modified membrane surface while water navigates and passes through membrane pore space and is collected as a permeate. 


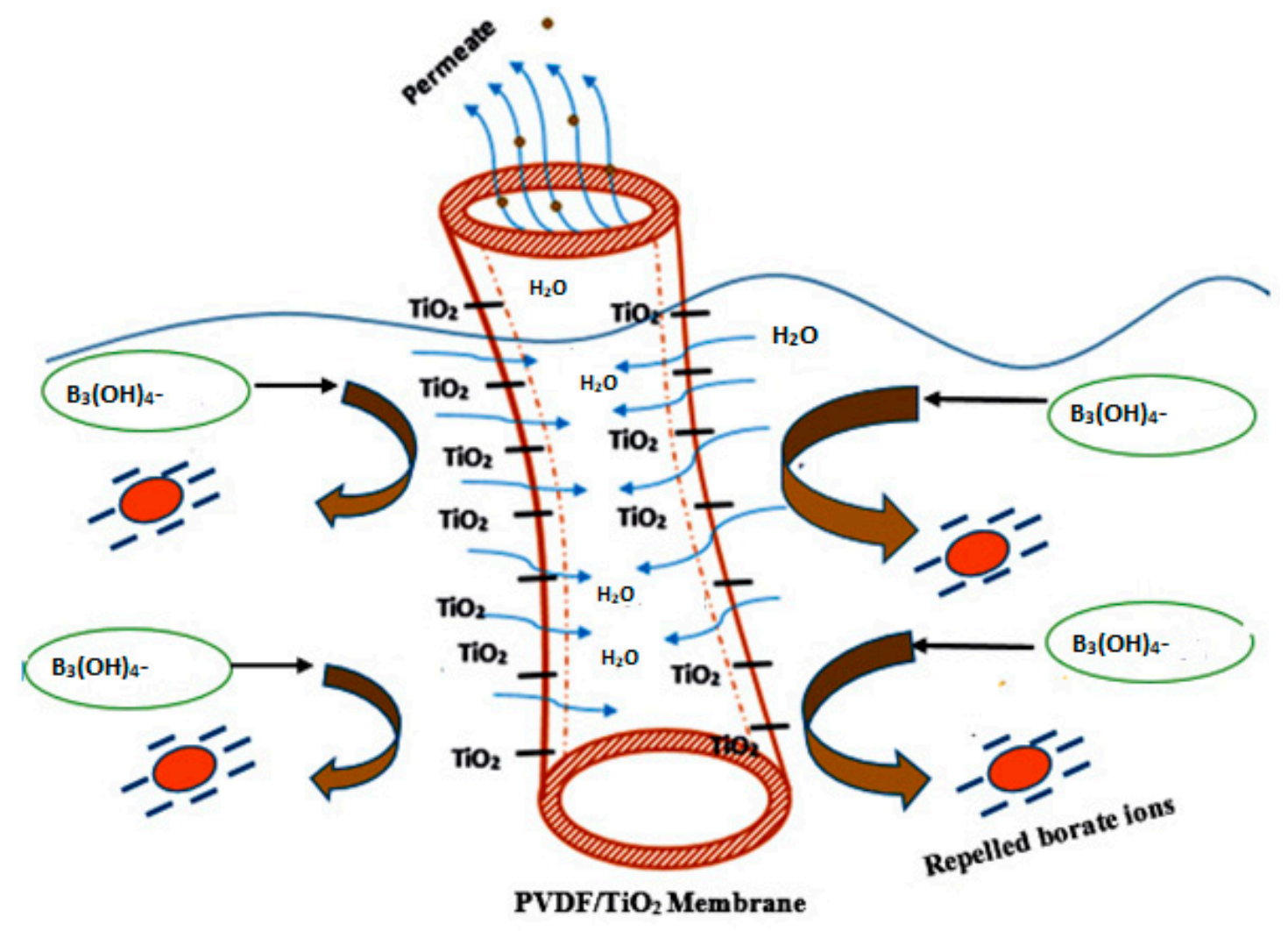

Figure 7. Boron rejection mechanism of the modified $\mathrm{PVDF} / \mathrm{PVP} / \mathrm{TiO}_{2}$ membrane.

\subsection{3. $\mathrm{TiO}_{2}$ Surface Charge}

A zeta potential analyzer was used to assess the surface charge of the PVDF-PVP virgin and modified membranes. Figure 8 presents the surface zeta potential of the fabricated membrane at the varied broad range of 2-10 $\mathrm{pH}$. As depicted in Figure 8, the membrane matrix became more negatively charged alongside increasing $\mathrm{TiO}_{2}$ loading. The $\mathrm{TiO}_{2}$ exposed to the membrane surface was hydrolyzed to form a hydroxide functional group in the presence of water. The protonation of $\mathrm{TiO}_{2}$ resulted in the deprotonation of the membrane surface [64]. Noticeably, the membrane with $1.0 \mathrm{wt} \% \mathrm{TiO}_{2}$ loading recorded the highest negative zeta potential charge at $\mathrm{pH} 10$, with a value of $-36.7 \mathrm{Mv}$. This is as a result of homogenous dispersion of the nanoparticles within the membrane matrix structure. The high jump in boron removal is attributed to the high negative zeta potential recorded at the $1.0 \mathrm{wt} \% \mathrm{TiO}_{2}$ loading rate, which results in a more considerable amount of hydroxide groups and changes in the overall structure of the membrane.

Both zeta potential and hydrophilicity are essential parameters in membrane characterization. The membrane surface zeta potential provides information about the possible electrostatic attraction/repulsion, which depends on the quality of the feed stream. 


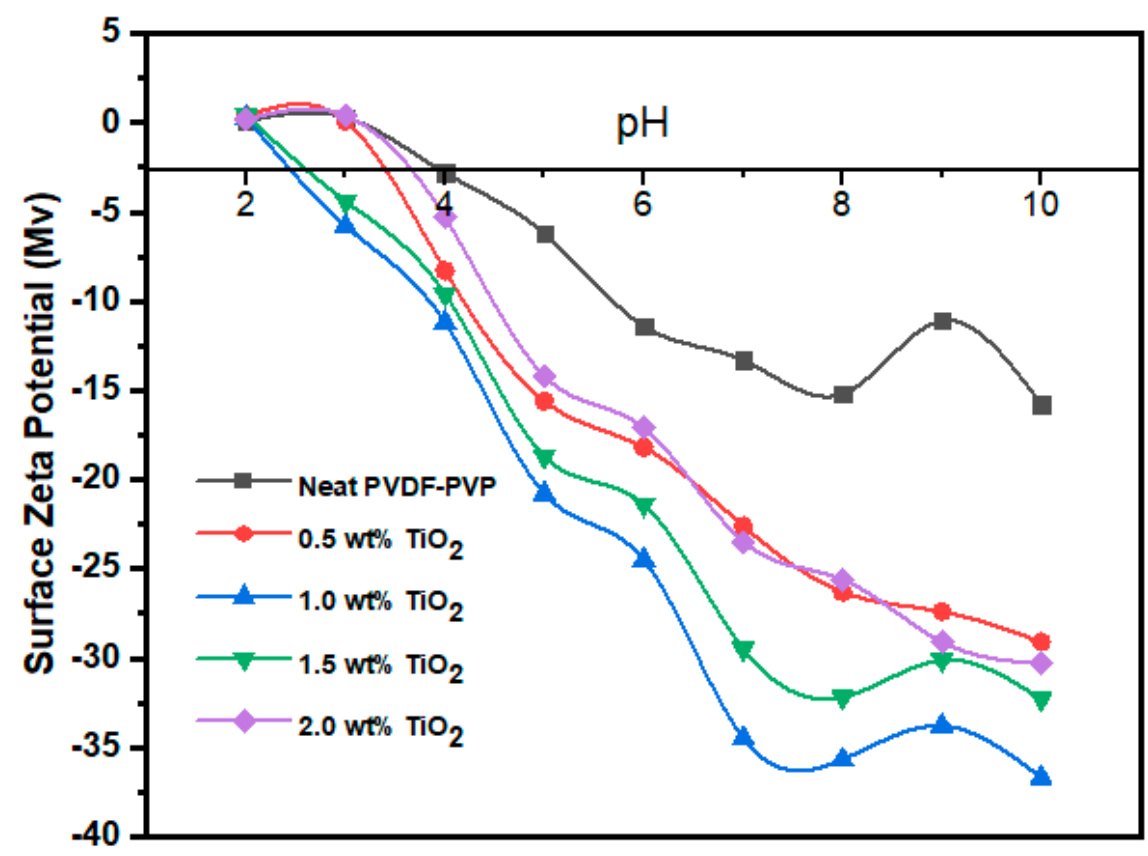

Figure 8. Surface zeta potential of neat PVDF-PVP and modified PVDF/PVP/TiO 2 membrane.

\subsubsection{Membrane Fouling Studies}

Figure 9 presents the results of flux in three cycles of filtration with respect to time. Generally, a decline in flux was noticed for both PVDF neat and modified membranes for the dosages of (a) neat, (b) 0.5 , (c) 1.0 , (d) 1.5 , and $2.0 \mathrm{wt} \%$ with time due to the deposition of foulants on the membrane surfaces. It was also observed that the neat PVDF membrane had a flux of $89 \mathrm{~L} / \mathrm{m}^{2} \cdot \mathrm{h}$, while the modified membrane $(1.0 \mathrm{wt} \%)$ had a flux of $157 \mathrm{~L} / \mathrm{m}^{2} \cdot \mathrm{h}$ after $200 \mathrm{~min}$ filtration. The flux further declines to 77 and $138 \mathrm{~L} / \mathrm{m}^{2} \cdot \mathrm{h}$ after the $700 \mathrm{~min}$ filtration period, respectively.

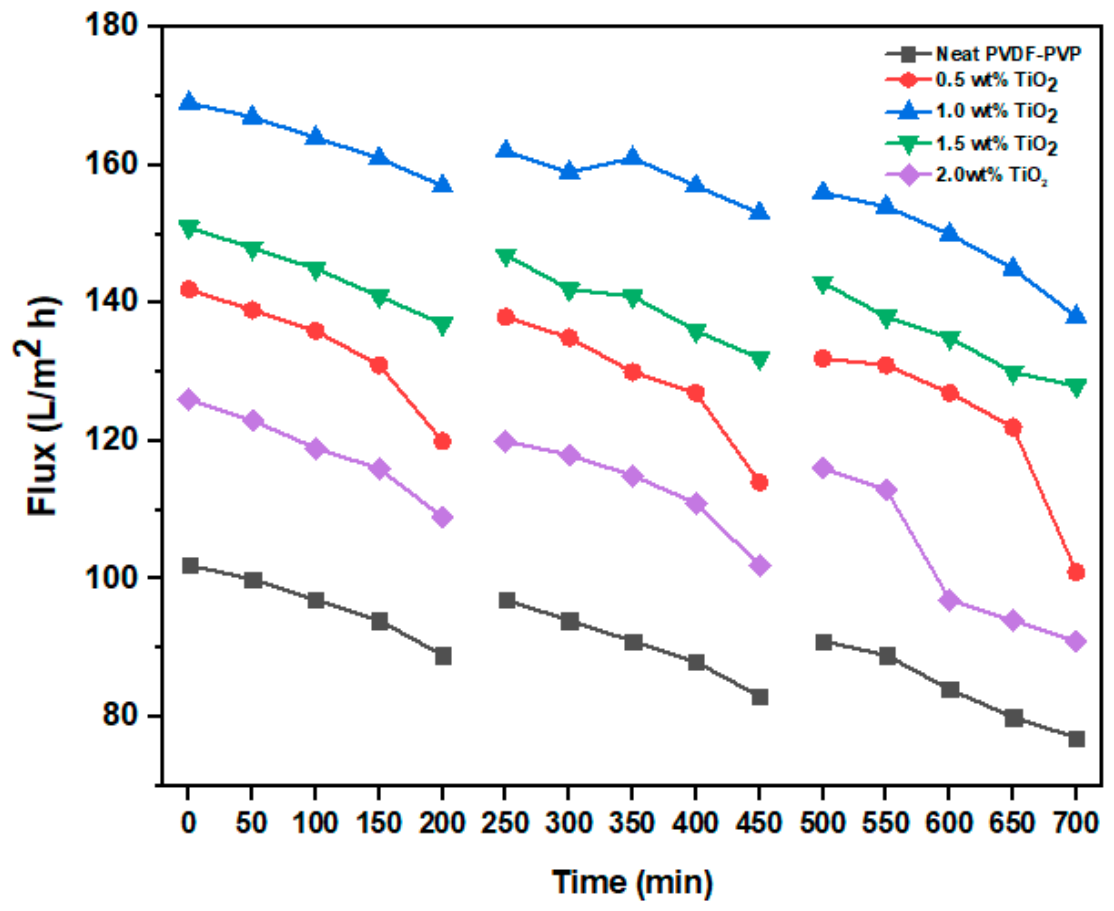

Figure 9. Antifouling and recycling properties of hollow fiber membranes as a function of time. 
Owing to the strong adhesive attraction existing between the interacting interfaces, hydrophobic membranes are more prone to fouling [54]. The incorporation of hydrophilic nanoparticles into the membrane structure can address foulant deposition. On this note, membranes with different dosages of $\mathrm{TiO}_{2}((\mathrm{a}) 0$, (b) 0.5, (c) 1.0, (d) 1.5, and (e) $2.0 \mathrm{wt} \%$ ) were subjected to three leachate filtration cycles with $200 \mathrm{~min}$ for each cycle to investigate the antifouling properties of the membranes. The leachate concentration of the feed was maintained as $8.2 \mathrm{mg} / \mathrm{L}$ for each of the cycles. The membranes were physically cleaned under running tap water for $30 \mathrm{~min}$ after every filtration cycle. The results of the relative flux reduction (RFR) and flux recovery ratio (FRR) are presented in Figure 10. From the first cycle, the modified membrane $\left(1.0 \mathrm{wt} \% \mathrm{TiO}_{2}\right)$ had the highest $\mathrm{FRR}$ of $92.82 \%$, while the neat membrane had $83.2 \%$. The FRRs of $0.5,1.0,1.5$, and $2.0 \mathrm{wt} \% \mathrm{TiO}_{2}$-modified membranes were $90.30 \%, 89.37 \%$, and $82.58 \%$, respectively. In addition, the fouling resistance performance of the modified membranes also outperformed the neat membrane. The \%RFR values for $0.5 \mathrm{wt} \% \mathrm{TiO}_{2}, 1.0 \mathrm{wt} \% \mathrm{TiO}_{2}, 1.5 \mathrm{wt} \%$ $\mathrm{TiO}_{2}$, and $2 \mathrm{wt} \% \mathrm{TiO}_{2}$ were $25.68 \%, 9.91 \%, 14.42 \%$, and $24.15 \%$, respectively, compared to $27.68 \%$ for the neat membrane. Noticeably, even at the end of the third filtration (cycle 3), the modified membrane with $1.0 \mathrm{wt} \% \mathrm{TiO}_{2}$ still recorded a high \%FRR of 76.25 with \%RFR of 12.34 .

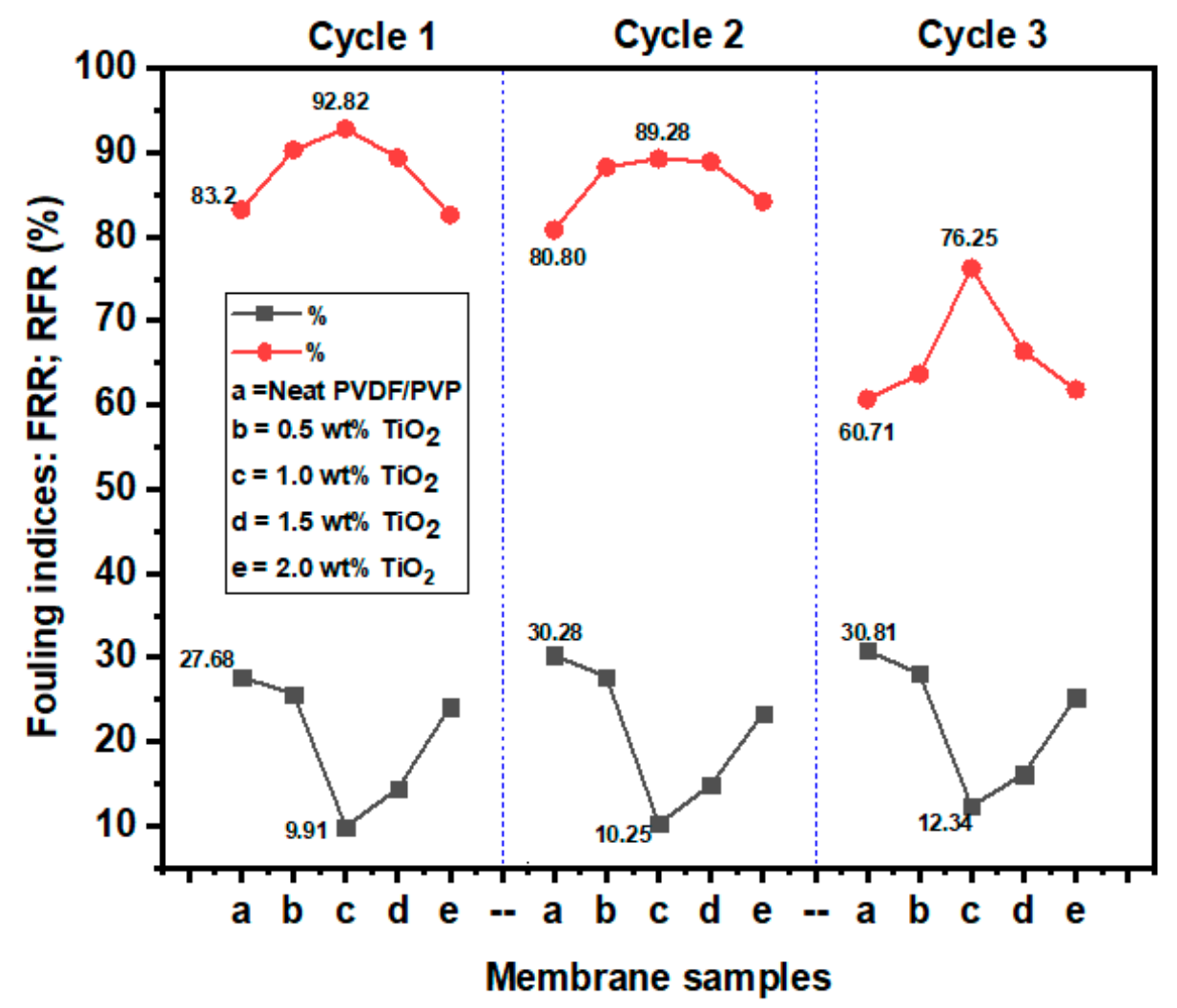

Figure 10. Percent relative flux reduction (\%RFR) and percent flux recovery ratio (\%FRR) in three filtration cycles using leachate as feed.

Generally, the \%RFR and \%FRR deteriorated along the filtration cycles. The first cycle filtration recorded higher \%FRR than the second and third cycles due to fouling. The good antifouling performance of the modified membranes was due to the blending of $\mathrm{TiO}_{2}$ nanoparticles into the membrane matrix. This is because hydrophilic nanoparticles have the potential to repel hydrophobic contaminants, thereby enhancing the antifouling property of the membrane [65-67].

\section{Conclusions}

The neat PVDF membrane and modified $\mathrm{PVDF} / \mathrm{TiO}_{2}$ membranes were prepared using the phase inversion method. The nano- $\mathrm{TiO}_{2}$ loading was varied from 0 to $2.0 \mathrm{wt} \%$. It was observed from this study 
that this additive enhances the hydrophilicity, porosity, flux, boron rejection, and antifouling properties of the spun membrane. Importantly, the membrane modified with $1.0 \mathrm{wt} \%$ loading demonstrated an unsurpassed performance, with 223 and $172 \mathrm{~L} / \mathrm{m}^{2} \cdot \mathrm{h}$ flux for pure water and leachate filtration. In addition, the lowest contact angle and highest boron rejection of $50.01^{\circ}$ and $94.75 \%$ were obtained with the modified membrane $\left(1.0 \mathrm{wt} \% \mathrm{TiO}_{2}\right)$, respectively. After three cycles of continuous filtration for $9 \mathrm{~h}$, the modified membrane $(1.0 \mathrm{wt} \%)$ had the highest flux recovery ratios of $92.82 \%, 89.28 \%$, and $76.25 \%$ respectively. The outstanding performance of the modified membrane $\left(1.0 \mathrm{wt} \% \mathrm{TiO}_{2}\right)$ was perhaps due to the homogeneous distribution of the nanoparticles on the PVDF-PVP matrix. Therefore, the membrane modified with $1.0 \mathrm{wt} \% \mathrm{TiO}_{2}$ is strongly recommended for implementation in water and wastewater purification processes aimed at boron removal from landfill leachates.

Author Contributions: Conceptualization, M.U.A., H.C.M., and M.A.; methodology, M.U.A., H.C.M., R.S.A., and M.A.; software, M.U.A.; validation, M.U.A, A.I.I., M.H.H., R.S.A., and H.C.M.; formal analysis, M.U.A., H.C.M., and R.S.A.; investigation, M.U.A.; data curation, M.U.A.; writing-original draft preparation, M.U.A.; writing-review and editing, M.U.A., H.C.M., R.S.A., M.H.H., and M.A., visualization, M.U.A., H.C.M., and M.H.H.; supervision, H.C.M., R.S.A., M.H.H., and A.I.I.; project administration, H.C.M., R.S.A., and M.H.H.; funding acquisition, R.S.A., H.C.M., and M.U.A. All authors have read and agreed to the published version of the manuscript.

Funding: The authors would like to gratefully acknowledge Universiti Putra Malaysia (UPM) for the financial support of this work via UPM/700-1/2/GPPI/2017/954160 and 9580600.

Acknowledgments: The authors would like to gratefully acknowledge Universiti Putra Malaysia (UPM) for supporting and financing this work in the preparation, execution, and write-up.

Conflicts of Interest: The authors declare no conflict of interest.

\section{References}

1. Chianese, A.; Ranauro, R.; Verdone, N. Treatment of Landfill Leachate by Reverse Osmosis. Water Res. 1999, 33, 647-652. [CrossRef]

2. Aziz, S.Q.; Aziz, H.A.; Yusoff, M.S.; Bashir, M.J.K.; Umar, M. Leachate characterization in semi-aerobic and anaerobic sanitary landfills: A comparative study. J. Environ. Manag. 2010, 91, 2608-2614. [CrossRef] [PubMed]

3. Hossini, H.; Rezaee, A.; Ayati, B.; Mahvi, A.H. Optimizing ammonia volatilization by air stripping from aquatic solutions using response surface methodology (RSM). Desalin. Water Treat. 2016, 57, 11765-11772. [CrossRef]

4. Renou, S.; Givaudan, J.G.; Poulain, S.; Dirassouyan, F.; Moulin, P. Landfill leachate treatment: Review and opportunity. J. Hazard. Mater. 2008, 150, 468-493. [CrossRef] [PubMed]

5. Kheriji, J.; Hamrouni, B. Boron removal from brackish water by reverse osmosis and nanofiltration membranes: Application of Spiegler-Kedem model and optimization. Water Sci. Technol. Water Supply 2016, 16, 684-694. [CrossRef]

6. Lotti, P.; Gatta, G.D.; Demitri, N.; Guastella, G.; Rizzato, S.; Ortenzi, M.A.; Magrini, F.; Comboni, D.; Guastoni, A.; Fernandez-Diaz, M.T. Crystal chemistry and temperature behavior of the natural hydrous borate colemanite, a mineral commodity of boron. Phys. Chem. Miner. 2018, 45, 405-422. [CrossRef]

7. Guan, Z.; Lv, J.; Bai, P.; Guo, X. Boron removal from aqueous solutions by adsorption-A review. DES 2016, 383, 29-37. [CrossRef]

8. Kluczka, J.; Korolewicz, T.; Zołotajkin, M.; Adamek, J. Boron removal from water and wastewater using new polystyrene-based resin grafted with glycidol. Water Resour. Ind. 2015, 11, 46-57. [CrossRef]

9. Patrick, H.; Hening, H. Does only a boron play a structural role in the growing tissues of higher plants. Plant Soil 1997, 196, 211-215.

10. Fujita, Y.; Hata, T.; Nakamaru, M.; Iyo, T. A study of boron adsorption onto activated sludge. Bioresour. Technol. 2005, 96, 1350-1356. [CrossRef]

11. Department of Environment Malaysia, M.N.R. Environmental Requirements; Federal Government Administrative Centre 62574: Putrajaya, Malaysia, 2010.

12. Xu, Y.; Jiang, J. Technologies for Boron Removal. Ind. Eng. Chem. Res. 2008, 47, 16-24. [CrossRef] 
13. Chen, T.; Wang, Q.; Lyu, J.; Bai, P.; Guo, X. Boron removal and reclamation by magnetic magnetite (Fe3O4) nanoparticle: An adsorption and isotopic separation study. Sep. Purif. Technol. 2020, 231, 115930. [CrossRef]

14. Foo, K.Y.; Lee, L.K.; Hameed, B.H. Preparation of banana frond activated carbon by microwave induced activation for the removal of boron and total iron from landfill leachate. Chem. Eng. J. 2013, 223, $604-610$. [CrossRef]

15. Jiang, J.; Xu, C.Y.; Quill, A.K.; Simon, B.J.; Shettle, K.B. Mechanisms of Boron Removal with Electrocoagulation. Environ. Chem. 2006, 350-354. [CrossRef]

16. Savas, A. Electrocoagulation of synthetically prepared waters containing high concentration of NOM using iron cast electrodes. J. Hazard. Mater. 2007, 139, 373-380. [CrossRef]

17. Yilmaz, A.E.; Boncukcuo, R.; Kocakerim, M.M. A quantitative comparison between electrocoagulation and chemical coagulation for boron removal from boron-containing solution. J. Hazard. Mater. 2007, 149, 475-481. [CrossRef]

18. Figueras, M.J.; Borrego, J.J. New Perspectives in Monitoring Drinking Water Microbial Quality. Int. J. Environ. Res. Public Health 2010, 7, 4179-4202. [CrossRef]

19. Man, H.C.; Chin, W.H.; Zadeh, M.R.; Yusof, M.R.M. Adsorption potential of unmodified rice husk for boron removal. BioResources 2012, 7, 3810-3822.

20. Environ, E.; Pendergast, M.M.; Hoek, E.M. A review of water treatment membrane nanotechnologies. Energy Environ. Sci. 2011, 1946-1971. [CrossRef]

21. Zularisam, A.W.; Ismail, A.F.; Salim, R. Behaviours of natural organic matter in membrane filtration for surface water treatment-A review. Desalination 2006, 194, 211-231. [CrossRef]

22. Tan, Y.H.; Goh, P.S.; Ismail, A.F.; Ng, B.C.; Lai, G.S. Decolourization of aerobically treated palm oil mill effluent (AT-POME) using polyvinylidene fluoride (PVDF) ultrafiltration membrane incorporated with coupled zinc-iron oxide nanoparticles. Chem. Eng. J. 2017, 308, 359-369. [CrossRef]

23. Zinadini, S.; Rostami, S.; Vatanpour, V.; Jalilian, E. Preparation of antibiofouling polyethersulfone mixed matrix NF membrane using photocatalytic activity of ZnO/MWCNTs nanocomposite. J. Membr. Sci. 2017, 529, 133-141. [CrossRef]

24. Li, J.H.; Shao, X.S.; Zhou, Q.; Li, M.Z.; Zhang, Q.Q. The double effects of silver nanoparticles on the PVDF membrane: Surface hydrophilicity and antifouling performance. Appl. Surf. Sci. 2013, 265, 663-670. [CrossRef]

25. Mauter, M.S.; Okemgbo, K.C.; Osuji, C.O.; Elimelech, M.; Wang, Y.; Giannelis, E.P. Antifouling ultrafiltration membranes via post-fabrication grafting of biocidal nanomaterials. ACS Appl. Mater. Interfaces 2011, 3, 2861-2868. [CrossRef]

26. Elango, M.; Deepa, M.; Subramanian, R.; Musthafa, A.M. Synthesis, characterization of polyindole/Ag-ZnO nanocomposites and its antibacterial activity. J. Alloys Compd. 2017, 696, 391-401. [CrossRef]

27. Teow, Y.H.; Ahmad, A.L.; Lim, J.K.; Ooi, B.S. Preparation and characterization of PVDF/TiO2 mixed matrix membrane via in situ colloidal precipitation method. DES 2012, 295, 61-69. [CrossRef]

28. Subramaniam, M.N.; Goh, P.S.; Lau, W.J.; Tan, Y.H.; Ng, B.C.; Ismail, A.F. Hydrophilic hollow fiber PVDF ultrafiltration membrane incorporated with titanate nanotubes for decolourization of aerobically-treated palm oil mill effluent. Chem. Eng. J. 2017, 316, 101-110. [CrossRef]

29. Jhaveri, J.H.; Murthy, Z.V.P. A comprehensive review on anti-fouling nanocomposite membranes for pressure driven membrane separation processes. Desalination 2016, 379, 137-154. [CrossRef]

30. Meng, F.; Zhang, S.; Oh, Y.; Zhou, Z.; Shin, H.S.; Chae, S.R. Fouling in membrane bioreactors: An updated review. Water Res. 2017, 114, 151-180. [CrossRef]

31. Chae, H.R.; Lee, J.; Lee, C.H.; Kim, I.C.; Park, P.K. Graphene oxide-embedded thin-film composite reverse osmosis membrane with high flux, anti-biofouling, and chlorine resistance. J. Membr. Sci. 2015, 483, 128-135. [CrossRef]

32. Abdulsalam, M.; Man, H.C.; Goh, P.S.; Yunos, K.F.; Abidin, Z.Z.; Isma, M.I.A.; Ismail, A.F. Permeability and Antifouling Augmentation of a Hybrid PVDF-PEG Membrane Using Nano-Magnesium Oxide as a Powerful Mediator for POME Decolorization. Polymer 2020, 12, 549. [CrossRef] [PubMed]

33. Nasrollahi, N.; Vatanpour, V.; Aber, S.; Mahmoodi, N.M. Preparation and characterization of a novel polyethersulfone (PES) ultrafiltration membrane modified with a $\mathrm{CuO} / \mathrm{ZnO}$ nanocomposite to improve permeability and antifouling properties. Sep. Purif. Technol. 2018, 192, 369-382. [CrossRef] 
34. Yuan, Z.; Dan-Li, X. Porous PVDF/TPU blends asymmetric hollow fiber membranes prepared with the use of hydrophilic additive PVP (K30). Desalination 2008, 223, 438-447. [CrossRef]

35. Xu, Z.; Chung, T.; Huang, Y.U. Effect of Polyvinylpyrrolidone Molecular Weights on Morphology, Oil/Water Separation, Mechanical and Thermal Properties of Polyetherimide/Polyvinylpyrrolidone Hollow Fiber Membranes. J. Appl. Polym. Sci. 1999, 74, 2220-2233. [CrossRef]

36. Damodar, R.A.; You, S.J.; Chou, H.H. Study the self cleaning, antibacterial and photocatalytic properties of TiO2 entrapped PVDF membranes. J. Hazard. Mater. 2009, 172, 1321-1328. [CrossRef]

37. Teow, Y.H.; Ooi, B.S.; Ahmad, A.L. Study on PVDF-TiO2 mixed-matrix membrane behaviour towards humic acid adsorption. J. Water Process Eng. 2017, 15, 99-106. [CrossRef]

38. Ramanavicius, S.; Tereshchenko, A.; Karpicz, R.; Ratautaite, V.; Bubniene, U.; Maneikis, A.; Jagminas, A.; Ramanavicius, A. TiO2-x/TiO2-Structure Based 'Self-Heated' Sensor for the Determination of Some Reducing Gases. Sensors 2020, 20, 74. [CrossRef]

39. Wang, Y.; Wu, T.; Zhou, Y.; Meng, C.; Zhu, W.; Liu, L. TiO2-Based Nanoheterostructures for Promoting Gas Sensitivity Performance: Designs, Developments, and Prospects. Sensors 2017, 35, 1971. [CrossRef]

40. Oh, S.J.; Kim, N.; Lee, Y.T. Preparation and characterization of PVDF/TiO2 organic-inorganic composite membranes for fouling resistance improvement. J. Membr. Sci. 2009, 345, 13-20. [CrossRef]

41. Zeng, G.; He, Y.; Yu, Z.; Zhan, Y.; Ma, L.; Zhang, L. Preparation and characterization of a novel PVDF ultrafiltration membrane by blending with TiO2-HNTs nanocomposites. Appl. Surf. Sci. 2016, 371, $624-632$. [CrossRef]

42. Zhang, F.; Zhang, W.; Yu, Y.; Deng, B.; Li, J.; Jin, J. Sol-gel preparation of PAA-g-PVDF/TiO2 nanocomposite hollow fiber membranes with extremely high water flux and improved antifouling property. J. Membr. Sci. 2013, 432, 25-32. [CrossRef]

43. Fulfillment, I.P.; Hu, W.; Supervisor, T. Fabrication of TiO2-Embedded PVDF Membranes and Their Application in Algae Membrane Bioreactor Systems. Master's Thesis, University of Missouri, Columbia, MO, USA, 2013.

44. Fan, L.; Shi, J.; Xi, Y. PVDF-Modified Nafion Membrane for Improved Performance of MFC. Membranes 2020, 10, 185. [CrossRef] [PubMed]

45. Wang, H.; Gong, R.; Qian, X. Preparation and characterization of TiO2/g-C3N4/PVDF composite membrane with enhanced physical properties. Membranes 2018, 8, 14. [CrossRef] [PubMed]

46. Razmjou, A.; Mansouri, J.; Chen, V. The effects of mechanical and chemical modification of TiO2 nanoparticles on the surface chemistry, structure and fouling performance of PES ultrafiltration membranes. J. Membr. Sci. 2011, 378, 73-84. [CrossRef]

47. Liu, Y.; Xiao, T.; Bao, C.; Zhang, J.; Yang, X. Performance and fouling study of asymmetric PVDF membrane applied in the concentration of organic fertilizer by direct contact membrane distillation (DCMD). Membranes 2018, 8, 9. [CrossRef] [PubMed]

48. Liu, Q.; Huang, S.; Zhang, Y.; Zhao, S. Comparing the antifouling effects of activated carbon and TiO2 in ultrafiltration membrane development. J. Colloid Interface Sci. 2018, 515, 109-118. [CrossRef] [PubMed]

49. Méricq, J.P.; Mendret, J.; Brosillon, S.; Faur, C. High performance PVDF-TiO2 membranes for water treatment. Chem. Eng. Sci. 2015, 123, 283-291. [CrossRef]

50. Hikku, G.S.; Jeyasubramanian, K.; Vignesh Kumar, S. Nanoporous MgO as self-cleaning and anti-bacterial pigment for alkyd based coating. J. Ind. Eng. Chem. 2017, 52, 168-178. [CrossRef]

51. Han, B.; Liang, S.; Wang, B.; Zheng, J.; Xie, X.; Xiao, K.; Wang, X.; Huang, X. Simultaneous determination of surface energy and roughness of dense membranes by a modified contact angle method. Colloids Surf. A Physicochem. Eng. Asp. 2019, 562, 370-376. [CrossRef]

52. Kim, S.H.; Kwak, S.-Y.; Sohn, B.-H.; Park, T.H. Design of TiO2 nanoparticle self-assembled aromatic polyamide thin-film-composite (TFC) membrane as an approach to solve biofouling problem. J. Membr. Sci. 2003, 211, 157-165. [CrossRef]

53. Zhu, Z.; Jiang, J.; Wang, X.; Huo, X.; Xu, Y.; Li, Q.; Wang, L. Improving the hydrophilic and antifouling properties of polyvinylidene fluoride membrane by incorporation of novel nanohybrid GO@SiO2 particles. Chem. Eng. J. 2017, 314, 266-276. [CrossRef]

54. Jayalakshmi, A.; Kim, I.; Kwon, Y. Suppression of gold nanoparticle agglomeration and its separation via nylon membranes. Chinese J. Chem. Eng. 2017, 25, 931-937. [CrossRef] 
55. Bae, T.H.; Tak, T.M. Effect of $\mathrm{TiO} 2$ nanoparticles on fouling mitigation of ultrafiltration membranes for activated sludge filtration. J. Membr. Sci. 2005, 249, 1-8. [CrossRef]

56. Yang, Y.; Zhang, H.; Wang, P.; Zheng, Q.; Li, J. The influence of nano-sized TiO2 fillers on the morphologies and properties of PSF UF membrane. J. Membr. Sci. 2007, 288, 231-238. [CrossRef]

57. Lai, S.O. Antifouling Improvement of Polyethersulfone Membrane Incorporated with Negatively Charged Zinc-Iron Oxide for AT-POME Colour Removal. Arab. J. Sci. Eng. 2019, 44. [CrossRef]

58. Taylor, P.; Ong, C.S.; Lau, W.J.; Goh, P.S.; Ng, B.C.; Matsuura, T.; Ong, C.S.; Lau, W.J.; Goh, P.S.; Ng, B.C.; et al. Separation Science and Technology Effect of PVP Molecular Weights on the Properties of PVDF-TiO2 Composite Membrane for Oily Wastewater Treatment Process Effect of PVP Molecular Weights on the Properties of PVDF-TiO2 Composite Membrane for Oily Wastewater treatment Process. Membranes 2014, 37-41. [CrossRef]

59. Simone, S.; Galiano, F.; Faccini, M.; Boerrigter, M.E.; Chaumette, C.; Drioli, E.; Figoli, A. Preparation and Characterization of Polymeric-Hybrid PES/TiO2 Hollow Fiber Membranes for Potential Applications in Water Treatment. Fibers 2017, 5, 14. [CrossRef]

60. Liu, C.; Lee, J.; Small, C.; Ma, J.; Elimelech, M. Comparison of organic fouling resistance of thin-film composite membranes modified by hydrophilic silica nanoparticles and zwitterionic polymer brushes. J. Membr. Sci. 2017, 544, 135-142. [CrossRef]

61. Shi, F.; Ma, Y.; Ma, J.; Wang, P.; Sun, W. Preparation and characterization of PVDF/TiO2 hybrid membranes with different dosage of nano-TiO2. J. Membr. Sci. 2012, 389, 522-531. [CrossRef]

62. Younas, H.; Bai, H.; Shao, J.; Han, Q.; Ling, Y.; He, Y. Super-hydrophilic and fouling resistant PVDF ultrafiltration membranes based on a facile prefabricated surface. J. Membr. Sci. 2017, 541, 529-540. [CrossRef]

63. Henmi, M.; Fusaoka, Y.; Tomioka, H.; Kurihara, M. High performance RO membranes for desalination and wastewater reclamation and their operation results. Water Sci. Technol. 2010, 62, 2134-2140. [CrossRef] [PubMed]

64. Pedersen, M.L.K.; Jensen, T.R.; Kucheryavskiy, S.V.; Simonsen, M.E. Investigation of surface energy, wettability and zeta potential of titanium dioxide/graphene oxide membranes. J. Photochem. Photobiol. A Chem. 2018, 366, 162-170. [CrossRef]

65. Ghanbari, M.; Emadzadeh, D.; Lau, W.J.; Matsuura, T.; Davoody, M.; Ismail, A.F. Super hydrophilic TiO2/HNT nanocomposites as a new approach for fabrication of high performance thin film nanocomposite membranes for FO application. Desalination 2015, 371, 104-114. [CrossRef]

66. Jamshidi Gohari, R.; Halakoo, E.; Nazri, N.A.M.; Lau, W.J.; Matsuura, T.; Ismail, A.F. Improving performance and antifouling capability of PES UF membranes via blending with highly hydrophilic hydrous manganese dioxide nanoparticles. Desalination 2014, 335, 87-95. [CrossRef]

67. Daraei, P.; Madaeni, S.S.; Ghaemi, N.; Khadivi, M.A.; Astinchap, B.; Moradian, R. Enhancing antifouling capability of PES membrane via mixing with various types of polymer modified multi-walled carbon nanotube. J. Membr. Sci. 2013, 444, 184-191. [CrossRef]

Publisher's Note: MDPI stays neutral with regard to jurisdictional claims in published maps and institutional affiliations.

(C) 2020 by the authors. Licensee MDPI, Basel, Switzerland. This article is an open access article distributed under the terms and conditions of the Creative Commons Attribution (CC BY) license (http://creativecommons.org/licenses/by/4.0/). 